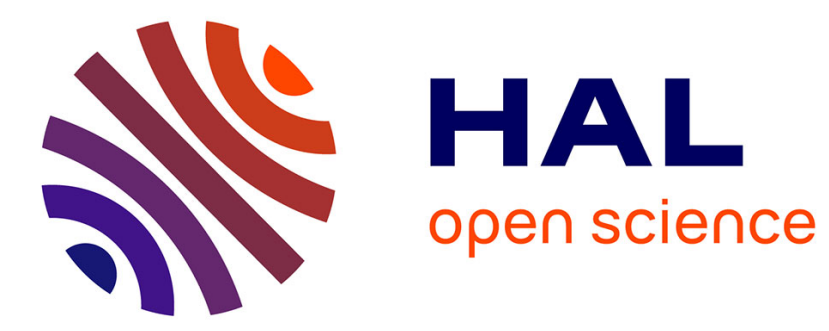

\title{
Breeding experience and demographic response to environmental variability in the white stork
}

Marie Nevoux, Jean-Claude Barbraud, Christophe Barbraud

\section{To cite this version:}

Marie Nevoux, Jean-Claude Barbraud, Christophe Barbraud. Breeding experience and demographic response to environmental variability in the white stork. Condor, 2008, 110 (1), pp.55-62. 10.1525/cond.2008.110.1.55 . hal-02664913

\section{HAL Id: hal-02664913 https://hal.inrae.fr/hal-02664913}

Submitted on 31 May 2020

HAL is a multi-disciplinary open access archive for the deposit and dissemination of scientific research documents, whether they are published or not. The documents may come from teaching and research institutions in France or abroad, or from public or private research centers.
L'archive ouverte pluridisciplinaire HAL, est destinée au dépôt et à la diffusion de documents scientifiques de niveau recherche, publiés ou non, émanant des établissements d'enseignement et de recherche français ou étrangers, des laboratoires publics ou privés. 


\title{
BREEDING EXPERIENCE AND DEMOGRAPHIC RESPONSE TO ENVIRONMENTAL VARIABILITY IN THE WHITE STORK
}

\author{
Marie Nevoux $^{1}$, Jean-Claude Barbraud ${ }^{2,3}$, And Christophe Barbraud ${ }^{1,2,4}$ \\ ${ }^{1}$ Centre d'Etudes Biologiques de Chizé, Centre National de la Recherche Scientifique, 79360 Villiers en Bois, France \\ ${ }^{2}$ GOAS, Palais des Congrès, 17300 Rochefort, France \\ ${ }^{3}$ La Nougerée, Bercloux, 17770 Brizambourg, France
}

\begin{abstract}
Whereas demographic performance increases with experience, little is known about the experiencerelated response of demographic performance to environmental variations. In long-lived birds, theoretical studies consider experience-related differences in performance to be greater under more restrictive conditions, but this has rarely been tested. We tested this hypothesis on the White Stork (Ciconia ciconia), using a long-term capturemark-recapture dataset. We studied the demographic response of a population from Western Europe to climate by analyzing adult survival and breeding success as a function of breeding experience. Birds reproduced less well during their first breeding event than during subsequent ones, suggesting that they undergo a learning process. In addition, high mortality in storks inexperienced at breeding may reflect an important cost associated with the first reproduction event. Presumably, birds subject to the highest cost of reproduction would die during the ensuing winter, with selection favoring birds able to maximize their survival. The first reproductive occasion could be considered a key event for White Storks, for whom mean breeding performance as well as survival probability increased over time in the population, likely as a result of a combination of learning and selection processes. Interannual variation of breeding success was partly explained by spring precipitation on the breeding ground, reflecting environmental variation. By contrast, winter conditions in the Sahel could not explain fluctuations of the survival. Contrary to our predictions, over this 12 -year study, inexperienced individuals seemed to be affected by climatic fluctuations, regardless of their severity, in the same manner as experienced ones.
\end{abstract}

Key words: Adult survival, breeding experience, breeding success, Ciconia ciconia, environmental variation, White Stork.

\section{Experiencia de Cría y Respuesta Demográfica a la Variabilidad Ambiental en Ciconia ciconia}

Resumen. Si bien se sabe que el desempeño demográfico incrementa con la experiencia, poco se conoce sobre la respuesta del desempeño demográfico vinculada a la experiencia de las variaciones ambientales. En las aves longevas, los estudios teóricos consideran que las diferencias en el desempeño vinculadas a la experiencia son mayores bajo condiciones más restrictivas, pero esto ha sido raramente evaluado. En este estudio, evaluamos esta hipótesis en Ciconia ciconia, empleando una base de datos de captura, marcado y recaptura de largo plazo. Estudiamos la respuesta demográfica de una población de Europa Occidental al clima, mediante el análisis de la supervivencia de los adultos y del éxito reproductivo como una función de la experiencia de cría. Las aves se reprodujeron con menos eficiencia durante sus primeros eventos reproductivos que durante los eventos subsecuentes, sugiriendo que éstas pasan por un proceso educativo. De modo adicional, la alta mortalidad en las cigüeñas sin experiencia reproductiva puede reflejar un costo importante asociado con el primer evento reproductivo. En teoría, las aves que sufren los mayores costos reproductivos deberían morir durante el invierno siguiente, con la selección favoreciendo a las aves capaces de maximizar su supervivencia. El primer evento reproductivo puede ser considerado como clave para C. ciconia. En esta especie, el desempeño reproductivo promedio y la probabilidad de supervivencia incrementaron con el tiempo en la población, probablemente como resultado de una combinación de procesos de aprendizaje y de selección. La variación interanual en el éxito reproductivo se explicó parcialmente por las lluvias de primavera en el área de cría, reflejando la variación ambiental. En contraste, las condiciones de invierno en el Sahel no pudieron explicar las fluctuaciones en la supervivencia. Contrariamente a nuestras predicciones, a lo largo de este estudio de 12 años, los individuos inexpertos parecieron estar afectados por las fluctuaciones climáticas, independientemente de su severidad, del mismo modo que los individuos experimentados.

Manuscript received 23 January 2007; accepted 9 October 2007.

${ }^{4}$ E-mail: barbraud@cebc.cnrs.fr

The Condor, Vol. 110, Issue 1, pages 55-62. ISSN 0010-5422, electronic ISSN 1938-5422. (c) 2008 by The Cooper Ornithological Society. All rights reserved. Please direct all requests for permission to photocopy or reproduce article content through the University of California Press's Rights and Permissions website, http://www.ucpressjournals.com/reprintInfo.asp. DOI: $10.1525 /$ cond.2008.110.1.55. 


\section{INTRODUCTION}

In mammalian and avian populations, several studies have found evidence of a general pattern where individuals breeding for the first time have a lower probability of breeding successfully (Forslund and Pärt 1995, Newton 1998, Reid et al. 2003), a higher probability of skipping breeding in the following year (Weimerskirch 1990, Viallefont et al. 1995), and a lower probability of surviving after first reproduction (Clutton-Brock et al. 1996, Reid et al. 2003) compared to older and more experienced individuals. This distinction in the performance of individuals among experience classes is an important variable of population dynamics. Based on the ability of each class to face perturbations, the impact of climatic fluctuations on population dynamics may depend on population structure. It appears that differences in breeding performance (Ratcliffe et al. 1998, Laaksonen et al. 2002, Bunce et al. 2005) and survival probability (Gaillard et al. 1998, Coulson et al. 2001, Barbraud and Weimerskirch 2005) of breeding birds of younger and prime ages is particularly important during harsh weather conditions. At the intrapopulation level, we can consider this distinction between birds inexperienced and experienced at breeding fundamental to better explaining population dynamics in variable ecosystems.

In addition, the demographic response of a population to its environment may depend on its specific life history traits, such as the manner in which it deals with the trade-off for the allocation of resources between reproduction and survival (Erikstad et al. 1998). In long-lived birds, the survival of adults in general, and experienced ones in particular, should be highly buffered against external forces, at the expense of breeding success (Gaillard et al. 2000, Pfister 2005). In short-lived species, the opposite pattern is expected (Sæther and Bakke 2000). This issue has been examined in the extremely longlived Black-browed Albatross (Thalassarche melanophrys), for whom the response of adult survival to climatic indices depends on the experience of individuals, whereas the impact of climate on breeding success is similar, irrespective of experience (Nevoux et al. 2007).

The objective of this study is to test whether this result - the influence of the breeding experience on the impact of climate on survival, but not on breeding success - could be extended to another long-lived species characterized by high fecundity. The White Stork (Ciconia ciconia) is a long-lived (average lifespan 20-30 years) migrant bird that faces highly variable environments throughout its life cycle (Géroudet 1994). Indeed, previous studies have highlighted the impact of climatic variations on the population size (Sæther et al. 2006) and on the mortality of European White Stork populations (Kanyamibwa et al. 1990, 1993, Barbraud et al. 1999, Schaub et al. 2005), indicating a certain susceptibility of this species to the fluctuations of its environment. First, we estimated the breeding success and adult survival probability of storks inexperienced and experienced at breeding, using long-term capture-mark-recapture datasets. Next, we tested for correlations between environmental fluctuations and demographic parameters in order to study potential experience-based responses of breeding individuals to climatic fluctuations, which has rarely been assessed in relation to both reproductive success and survival probability. Based on previous findings for birds (Laaksonen et al. 2002, Barbraud and Weimerskirch 2005, Bunce et al. 2005) and mammals (Gaillard et al. 1993, 1998, 2000, Coulson et al. 2001), we predicted that younger breeding storks should reproduce and survive less well than experienced breeding storks. We expected that this difference should increase under increasing climate severity, based on storks' respective ability to face environmental fluctuations.

\section{METHODS}

\section{SPECIES AND STUDY SITES}

The White Stork (Ciconiiformes) is a large (3-4 kg) water bird breeding mainly in Europe. Based on its migratory pattern, European populations can be segregated into western and eastern populations separated by a line from north Germany to Hungary. During winter, western birds migrate to the western sector of the Sahel, whereas eastern storks migrate to the eastern Sahelian sector and to southern Africa (Géroudet 1994, Berthold et al. 2001). Every year, birds start to return to breeding sites in mid-February and, in March, females lay on average three to five eggs each. Our study was conducted on a western population of storks breeding in the Brouage marshes, Charente-Maritime, western France $\left(45.5^{\circ} \mathrm{N}, 1.0^{\circ} \mathrm{W}\right)$, where artificial and natural nests were established in and around a marsh area. This study began in 1978, and 20-85 banded breeding pairs were monitored each year from 1992 to 2003 (Barbraud et al. 1999).

From the time of arrival of the breeding pairs to the departure of fledglings, each nest was checked with a telescope an average of five times in order to record the members and the number of chicks of each pair. Every year, each chick of the monitored pairs was banded with a stainless steel band and with a unique-numbered PVC (Darvic) band. In summer, during the breeding season, birds foraged in the marshes, feeding mainly on aquatic insects, crayfishes and anurans (Barbraud and Barbraud 1997, Barbraud et al. 2002). In winter, storks migrated to the Sahelian zone in Africa through Spain and the Gibraltar Strait (Géroudet 1994, Berthold et al. 2001, CB, unpubl. data). However, since the 1990s, an increasing number of birds have remained in southern Europe - mainly Spainduring the winter (Archaux et al. 2004).

\section{STATISTICAL ANALYSES}

Experience. Because White Storks are long-lived and mature at a late age (Barbraud et al. 1999), we selected the 
capture histories of breeding birds observed between 1992 and 2003 in order to obtain a sufficient number of sightings of individuals of known age and breeding history ( 724 breeding events recorded involving a total of 237 storks). In this population, $95 \%$ of birds were observed to begin breeding at between two and five years of age; age and experience were thus not confounded in this population (MN, unpubl. data). We classified adult birds according to their experience, defined as the number of breeding events. We assumed that the first reproductive event was correctly detected, based on the high probability of observing breeding storks in the breeding area (see Results). A first analysis consisted of modeling survival for different classes of experience. The model specified the minimum number of experience classes $(x)$ needed to discriminate individuals by their survival probability.

Breeding success. Breeding success was defined for each individual at the end of each reproductive season as the number of fledglings produced. The effect of experience on breeding success was assessed using the $x$ experience class defined above. The relationships between breeding success and experience or climatic indices were tested using nonparametric mixed models with random effects on individuals, as data were neither normally distributed (Shapiro-Wilk test: $W=0.91$, $P<0.001$ ) nor independent (the breeding success of individuals that reproduced several times during the study period was recorded several times, as storks both inexperienced and experienced at breeding). Models with climatic covariates were selected using the analysis of deviance ANODEV test, which provides a statistic for evaluating the impact of a covariate by comparing the amount of deviance explained by that covariate against the amount of deviance it leaves unexplained (Skalski et al. 1993, White and Burnham 1999). Statistics were computed using R (Ihaka and Gentleman 1996). Estimates are presented \pm SE.

Survival. Annual adult survival probabilities were estimated with capture-mark-recapture (CMR) models using MSURGE (Choquet et al. 2004). By taking into account the probability of detecting birds (i.e., the probability that a banded bird that is alive and in the study area at time $t$ was seen at time $t$ ), these models calculate unbiased estimates of annual apparent survival probabilities (Lebreton et al. 1992). First, a goodness-of-fit test was performed using U-CARE (Choquet et al. 2003) to test whether the data followed the assumptions on which CMR models are based (Lebreton et al. 1992). This test was performed on the more complex model $\Phi\left(\operatorname{Exp}^{*} t\right)$ $p\left(\operatorname{Exp}^{*} t\right)$, where both survival $(\Phi)$ and capture probabilities $(p)$ vary with experience $(\operatorname{Exp})$ and time $(t)$. Experience was modeled using $x$ classes, where "Expl" stands for individuals that breed for the first time, "Exp2" stands for individuals that breed for the second time, and so on.

Time-dependent models were selected using a second order Akaike's Information Criterion corrected for small sample sizes $\left(\mathrm{AIC}_{c}\right.$; Burnham and Anderson 1998). The model with the smallest $\mathrm{AIC}_{c}$ value was considered the best model. Two models separated by a difference in $\mathrm{AIC}_{c}$ values of less than two are assumed to fit the data similarly (Lebreton et al. 1992). Models with climatic covariates were selected using ANODEV. Estimates are presented $\pm \mathrm{SE}$.

\section{SELECTION OF ENVIRONMENTAL VARIABLES}

In most cases, climatic fluctuations are thought to affect populations through an indirect mechanism, whereby climate first affects primary production, with the disturbance then becoming integrated along the trophic web up to top predators. To limit the number of total covariates in the candidate models, we selected variables in accordance with the annual life cycle of White Stork, based on the seasonal presence of individuals in different ecosystems. Global indices were used to characterize environmental conditions over wintering areas. All included indices, description of which follow, were standardized over the study period (i.e., mean $=0, \mathrm{SD}=1$ ).

The North Atlantic Oscillation (NAO), calculated from differences in sea level pressure over the northern Atlantic Ocean, is known to affect many western European marine and terrestrial populations (Ottersen et al. 2001, Thompson and Ollason 2001, Stenseth et al. 2002). Winter NAO was obtained from the National Center for Atmospheric Research (NCAR; Hurrell 1995). In the terrestrial ecosystems exploited by storks (i.e., wetlands of the sub-Saharan zone in winter and European marshes in summer), the amount of precipitation is a key factor of primary production and was thus included as a covariate in our models. The Sahel Rainfall Index (SRI), based on the amount of precipitation over the sub-Saharan sector (i.e., 10.0 $20.0^{\circ} \mathrm{N}, 20.0^{\circ} \mathrm{W}-10.0^{\circ} \mathrm{E}$ ) has previously been found to affect storks' survival during winter (Kanyamibwa et al. 1990, 1993, Barbraud et al. 1999). We averaged SRI over the three wettest months from precipitation data (July-September; Janowiak 1988). Monthly SRI was available from the Joint Institute for the Study of the Atmosphere and Ocean (JISAO; Janowiak 1988, Mitchell 2005). We also selected precipitation (Pp) data in the vicinity of the study site in Charente-Maritime (45.0 $47.5^{\circ} \mathrm{N}, 2.5-0^{\circ} \mathrm{W}$ ) during the breeding season (February-July) to test for an impact of rainfall in this marsh area on the reproductive success of storks. Seasonal Pp was provided by the National Oceanic and Atmospheric Administration (NOAA; Chen et al. 2002, NOAA 2006). The Normalized Difference Vegetation Index (NDVI) is a measure of the greenness, related to primary production, measuring chlorophyll density from infrared satellite pictures. A recent study demonstrated that this index was correlated with the survival of eastern stork populations during winter (Schaub et al. 2005). To test whether NDVI influenced our stork population during winter, we extracted data from the Global Inventory Modeling and Mapping Studies (GIMMS; Tucker et al. 2005, GIMMS 2006) for the Sahelian sector during wintering months (SeptemberDecember). 


\section{RESULTS}

\section{EFFECT OF BREEDING EXPERIENCE}

Preliminary analysis of breeding experience indicated a difference in the survival probability between first-time breeding storks and those with two or more years of breeding experience (Table 1). Models with two, three, or four experience classes (respectively models 1-3) could not be discriminated by their $\mathrm{AIC}_{c}$ scores. Thus, we chose to define breeding experience as the distinction between the first and the second reproductive events $(x=2)$. Of the 724 breeding events (599 observed nests) recorded between 1992 and 2003, 237 were associated with inexperienced birds and 487 with experienced ones (Appendix). Among individuals breeding for the first time with a known (e.g., banded) bird, 45.2\% paired with a bird breeding for the first time as well.

\section{EFFECT OF EXPERIENCE AND CLIMATE ON SURVIVAL PROBABILITIES}

The goodness of fit test indicated that the initial capture-markrecapture model fit the White Stork dataset $\left(\chi^{2}{ }_{11}=6.8, P=\right.$ $0.81)$. All models of capture probability in which time was a variable had the highest $\mathrm{AIC}_{c}$ values (models 3-7, Table 2). The constant model (model 1) was the top model, suggesting that experience (model 2 ) did not affect probability of capture $(p=0.91 \pm 0.02)$.

The top model of adult survival was an additive one with experience and time as variables (model 8), where the survival probability of inexperienced adults as well as experienced ones varied in parallel (on a logit scale) over time (Fig. 1). Survival rates of inexperienced and experienced birds were respectively $0.71 \pm 0.04$ and $0.81 \pm 0.02$, being significantly more variable

TABLE 1. Models of the effect of breeding experience on survival probability using different experience classes for White Storks (Ciconia ciconia) in Charente-Maritime, France. Models are ranked by Akaike's information criterion corrected for small sample size $\left(\mathrm{AIC}_{c}\right)$. The number of estimated parameters is $K$, the difference in $\mathrm{AIC}_{c}$ from the top model is $\Delta \mathrm{AIC}_{c}$, and the model weight is $w_{i}$. For experience classes, e.g., $\operatorname{Exp}(1,2,3+)$ indicates a model with individuals pooled into 3 categories depending on their breeding experience: 1 = birds breeding for the first time, $2=$ birds breeding for the second time, and $3+=$ birds breeding for the third time or more.

\begin{tabular}{llcccc}
\hline \hline $\begin{array}{l}\text { Model } \\
\text { number }\end{array}$ & \multicolumn{1}{c}{ Model } & Likelihood & $K$ & $\Delta \mathrm{AIC}_{c}{ }^{\mathrm{a}}$ & $w_{i}$ \\
\hline 1 & $\operatorname{Exp}(1,2,3+)$ & 1.00 & 4 & 0.00 & 0.41 \\
2 & $\operatorname{Exp}(1,2+)$ & 0.54 & 3 & 1.23 & 0.22 \\
3 & $\operatorname{Exp}(1,2,3,4+)$ & 0.54 & 5 & 1.23 & 0.22 \\
4 & $\operatorname{Exp}(1,2,3,4,5+)$ & 0.22 & 6 & 2.97 & 0.09 \\
5 & $\operatorname{Exp}(1,2,3,4,5,6+)$ & 0.07 & 7 & 5.01 & 0.03 \\
6 & $\operatorname{Exp}(1+)$ & 0.07 & 2 & 5.31 & 0.03 \\
\hline
\end{tabular}

${ }^{\mathrm{a}} \mathrm{AIC}_{\mathrm{c}}$ of top model $=850.16$. in birds inexperienced at breeding than in experienced ones $\left(F_{8,7}=6.9, P=0.01\right)$.

The ANODEV indicated that our models with climatic covariates (models 14-16; Table 2) did not explain a significant portion of the variance in annual survival (all $P>0.05$ ). None of these models was able to identify a relationship between environmental variables and survival. Testing monthly indices (instead of a three-month average) did not improve the fit of the models, and neither were any significant correlations between survival and environmental conditions detected.

\section{EFFECT OF EXPERIENCE AND CLIMATE ON BREEDING SUCCESS}

The breeding success of White Storks (Fig. 2A) varied over time (model 9 vs. model 3, Table 3) and with the breeding experience of birds in an additive fashion (model 1). Individuals breeding for the first time had lower breeding success ( $2.66 \pm 0.09$ fledglings per year) compared to experienced breeders ( $2.98 \pm 0.07$ fledglings). The variance in the breeding success between the two experience groups was not significantly different over the study period $\left(F_{11,11}=1.4, P=0.29\right)$.

Interyear variation in the breeding success of both inexperienced and experienced birds as explained by precipitation on the breeding sector in spring $\left(P_{\mathrm{ANODEV}}=0.05, R^{2}=0.40\right.$; model 4, Table 3; Fig. 2B and C), a relationship driven mainly by precipitation in the month of April $\left(P_{\mathrm{ANODEV}}=0.02, R^{2}=\right.$ $0.51)$. This result suggests that precipitation positively influences the breeding success of White Storks, regardless of their experience, with a $0.63 \pm 0.09$ increase in reproductive success with each increasing standardized unit of precipitation (model 4 vs. model 5). By contrast, we did not detect any relationship between breeding success and environmental conditions over wintering grounds (models 6-8).

\section{DISCUSSION}

Our study demonstrates that reproductive performance of White Storks depended on their breeding experience. Birds breeding for the first time had a $10 \%$ lower and more variable probability of surviving and a 19\% lower but equally variable probability of producing fledglings compared to those with experience. This result is in accordance with theoretical (Forslund and Pärt 1995, Newton 1998) and empirical (Cam and Monnat 2000, Gaillard et al. 2000, Reid et al. 2003, Barbraud and Weimerskirch 2005) studies.

Whereas reproductive success was related to the environmental conditions during spring in the breeding area, adult survival showed no response to climatic variables during the study period. We found a positive effect of the amount of precipitation on the breeding area in spring on the breeding success of storks. Indeed, the productivity of marshes, highly dependent on the rain, determined the quantity or the quality of food available for storks, which forage on aquatic insects, 
TABLE 2. Models of capture and survival probabilities including time, experience and climatic covariates for White Storks in CharenteMaritime, France. Models are ranked by Akaike's information criterion corrected for small sample size (AIC $C_{c}$ ). The number of estimated parameters is $K$, the difference in $\mathrm{AIC}_{c}$ from the top model is $\Delta \mathrm{AIC}_{c}$, the model weight is $w_{i}$, and $P$-value of the ANODEV test on climatic covariates is $P$-ANODEV. For effects, time $=\mathrm{t}$, experience $=$ Exp, including birds inexperienced $($ Exp1) and experienced $($ Exp2) at breeding, constant is designated by a period, North Atlantic oscillation = NAO, Sahel Index = SRI, normalized difference vegetation index in Sahel $=$ NDVI, and precipitation in Charente-Maritime $=\mathrm{Pp}$. Wintering and breeding seasons are designated by the subscripts ${ }_{\mathrm{w}}$ and $\mathrm{b}_{\mathrm{b}}$, respectively. Interaction or additivity among variables is indicated by an asterisk or plus sign, respectively.

\begin{tabular}{|c|c|c|c|c|c|c|}
\hline Model number & Model & $K$ & Likelihood & $\Delta \mathrm{AIC}_{c}{ }^{\mathrm{a}}$ & $w_{i}$ & $P$-ANODEV \\
\hline & Modeling capture probability & & & & & \\
\hline 1 & $\Phi\left(\operatorname{Exp}^{*} \mathrm{t}\right) \mathrm{p}()$. & 19 & 0.37 & 1.99 & 0.22 & \\
\hline 2 & $\Phi\left(\operatorname{Exp}^{*} \mathrm{t}\right) \mathrm{p}(\operatorname{Exp})$ & 20 & 0.13 & 4.14 & 0.08 & \\
\hline 3 & $\Phi\left(\operatorname{Exp}^{*} \mathrm{t}\right) \mathrm{p}(\operatorname{Exp} 1(\mathrm{t}) \operatorname{Exp} 2())$. & 25 & 0.03 & 6.96 & 0.02 & \\
\hline 4 & $\Phi\left(\operatorname{Exp}^{*} \mathrm{t}\right) \mathrm{p}(\operatorname{Exp} 1(.) \operatorname{Exp} 2(\mathrm{t}))$ & 26 & 0.00 & 11.06 & 0.00 & \\
\hline 5 & $\Phi\left(\operatorname{Exp}^{*} \mathrm{t}\right) \mathrm{p}\left(\operatorname{Exp}^{*} \mathrm{t}\right)$ & 30 & 0.00 & 11.94 & 0.00 & \\
\hline 6 & $\Phi\left(\operatorname{Exp}^{*} \mathrm{t}\right) \mathrm{p}(\operatorname{Exp}+\mathrm{t})$ & 28 & 0.00 & 19.00 & 0.00 & \\
\hline \multirow[t]{2}{*}{7} & $\Phi\left(\operatorname{Exp}^{*} \mathrm{t}\right) \mathrm{p}(\mathrm{t})$ & 28 & 0.00 & 19.06 & 0.00 & \\
\hline & Modeling survival probability & & & & & \\
\hline 8 & $\Phi(\operatorname{Exp}+\mathrm{t}) \mathrm{p}()$. & 12 & 1.00 & 0.00 & 0.60 & \\
\hline 9 & $\Phi(\operatorname{Exp} 1(\mathrm{t}) \operatorname{Exp} 2().) \mathrm{p}()$. & 11 & 0.09 & 4.93 & 0.05 & \\
\hline 10 & $\Phi(\operatorname{Exp} 1(.) \operatorname{Exp} 2(\mathrm{t})) \mathrm{p}()$. & 11 & 0.03 & 6.96 & 0.02 & \\
\hline 11 & $\Phi(\mathrm{t}) \mathrm{p}()$. & 11 & 0.01 & 10.41 & 0.00 & \\
\hline 12 & $\Phi(\operatorname{Exp}) \mathrm{p}()$. & 3 & 0.00 & 12.42 & 0.00 & \\
\hline \multirow[t]{2}{*}{13} & $\Phi(.) \mathrm{p}()$. & 2 & 0.00 & 16.50 & 0.00 & \\
\hline & Modeling climatic covariates & & & & & \\
\hline 14 & $\Phi\left(\operatorname{Exp}+\mathrm{NAO}_{\mathrm{w}}\right) \mathrm{p}()$. & 4 & 0.00 & 11.24 & 0.00 & 0.36 \\
\hline 15 & $\Phi\left(\operatorname{Exp}+\mathrm{NDVI}_{\mathrm{w}}\right) \mathrm{p}()$. & 4 & 0.00 & 13.77 & 0.00 & 0.68 \\
\hline 16 & $\Phi\left(\operatorname{Exp}+\mathrm{SRI}_{\mathrm{w}}\right) \mathrm{p}()$. & 4 & 0.00 & 13.99 & 0.00 & 0.74 \\
\hline 17 & $\Phi\left(\operatorname{Exp}+\mathrm{Pp}_{\mathrm{b}}\right) \mathrm{p}()$. & 4 & 0.00 & 14.13 & 0.00 & 0.78 \\
\hline
\end{tabular}

${ }^{\mathrm{a}}$ The lowest $\mathrm{AIC}_{c}$ value was 838.97.

crayfishes and anurans during the breeding season (Barbraud and Barbraud 1997, Barbraud et al. 2002). The state of the local environment at the beginning of the rearing period appeared to have a significant effect on the reproductive output. Although climatic factors appeared in the past to influence survival of

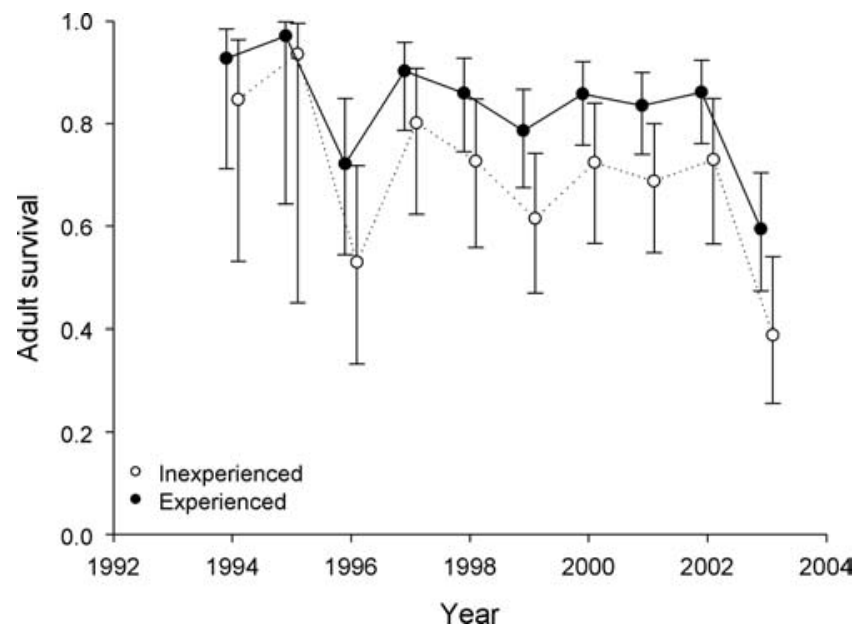

FIGURE 1. Survival probability of White Storks from CharenteMaritime, France, inexperienced $(n=231)$ and experienced $(n=$ $501)$ at breeding. Estimations $( \pm \mathrm{SE})$ are from model $\Phi(\operatorname{Exp}+\mathrm{t}) \mathrm{p}($. in Table 2, model 8, where Exp is experience, $\mathrm{t}$ is time, and the period indicates a constant effect. individuals in this population (Barbraud et al. 1999), we did not find any evidence of this in our study, for either inexperienced or experienced birds. Previous studies in eastern and western European stork populations have found relationships between stork survival and environmental conditions in their respective wintering grounds in Africa (Barbraud et al. 1999, Kanyamibwa et al. 1990, 1993, Schaub et al. 2005). This difference may be the result of change in the severity of the Sahel climate toward less droughty conditions, in the dependence of the population on environmental conditions (e.g., additional food resources provided by rubbish dumps; Archaux et al. 2004), or in the migratory behavior of storks (i.e., wintering in Southern Europe; Archaux et al. 2004).

Regarding experience-related response to climate, our findings for the White Stork contrast with results from previous studies on birds (Ratcliffe et al. 1998, Laaksonen et al. 2002, Barbraud and Weimerskirch 2005, Bunce et al. 2005) and large herbivores (Gaillard et al. 1993, 1998, 2000, Coulson et al. 2001). Differences between the performance of inexperienced and experienced individuals appear to be greater when food availability is reduced. Whereas Barbraud et al. (1999) found an interaction between survival of juvenile and adults storks and climate, Kanyamibwa et al. (1990) mention an additive effect of age and climate on adult survival probability. Climatic effects are indirect and therefore at best indicative. But even if we could not always identify the specific environmental 

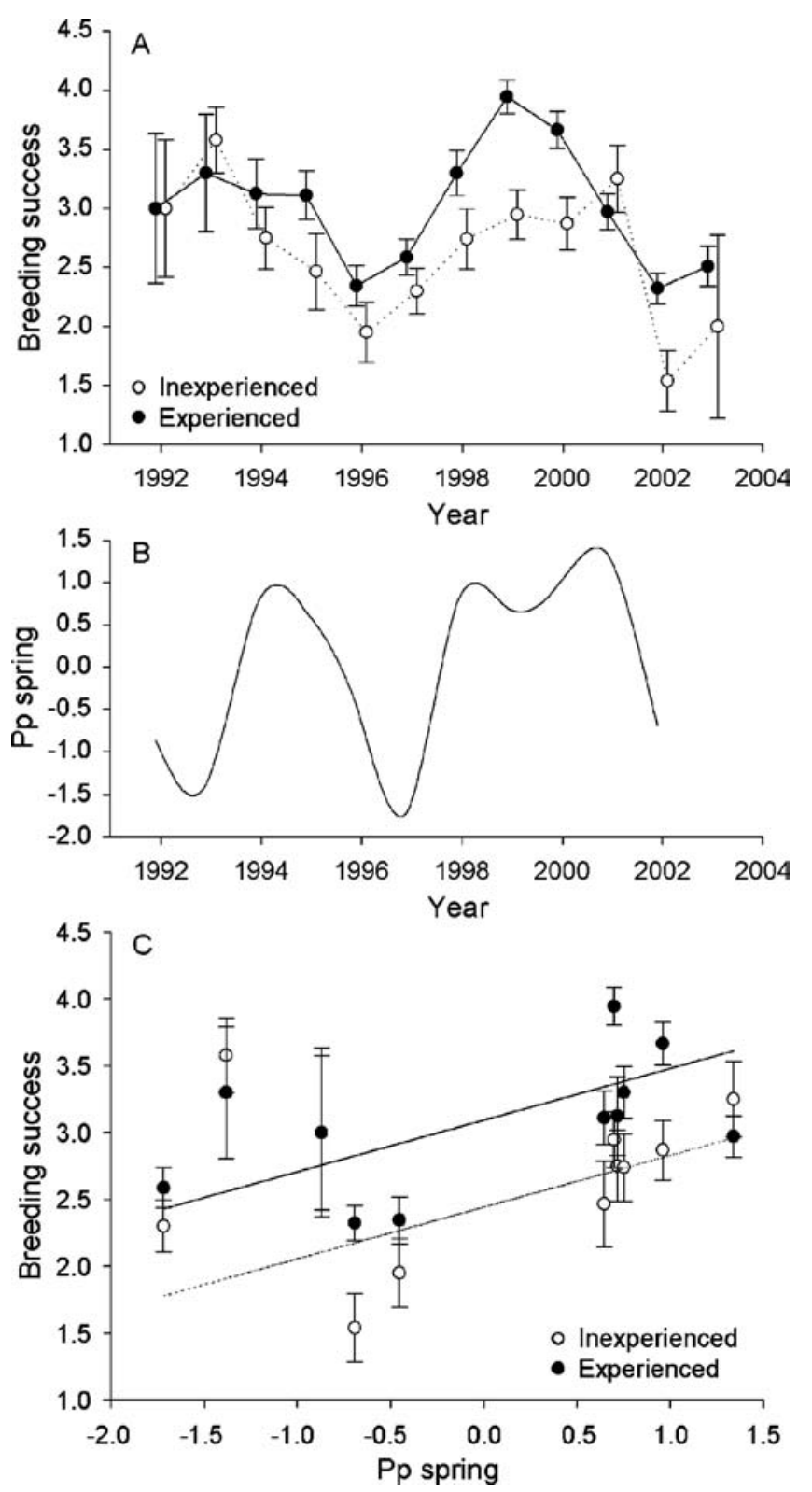

FIGURE 2. Breeding success and climatic index for White Storks in Charente-Maritime, France. (A) Breeding success $( \pm$ SE) for birds inexperienced $(n=231)$ and experienced $(n=501)$ at breeding. (B) Annual variation of the precipitation ( $\mathrm{Pp}$ ) in Charente Maritime in spring. (C) Relationship between breeding success and Pp in spring for storks inexperienced and experienced at breeding; mixed model: Breeding success $=$ Experience + Precipitation during reproduction (see Table 3, model 4). Pp was standardized to a normal distribution, with mean $=0$ and $\mathrm{SD}=1$.

parameters affecting breeding success or survival, they varied over time, and we suspect these variations to be due to interannual changes in environmental conditions. In addition, we obtained additive models between time and experience, indicating that the performance of storks inexperienced and
TABLE 3. Models of breeding success including time, experience, and climatic covariates for White Storks in Charente-Maritime, France. Models are ranked by Akaike's information criterion (AIC). The number of estimated parameters is $K$, the difference in AIC from the top model is $\triangle \mathrm{AIC}$, the model weight is $w_{i}$, and the $P$-value of the ANODEV test on climatic covariates is $P$-ANODEV. For effects, time $=\mathrm{t}$, experience $=$ Exp, constant is designated by a period, North Atlantic oscillation $=$ NAO, Sahel Index $=$ SRI, normalized difference vegetation index in Sahel = NDVI, and precipitation in Charente-Maritime $=\mathrm{Pp}$. Wintering and breeding seasons are designated by the subscripts ${ }_{\mathrm{w}}$ and ${ }_{\mathrm{b}}$, respectively. Interaction or additivity among variables is indicated by an asterisk or plus sign, respectively.

\begin{tabular}{|c|c|c|c|c|c|c|}
\hline $\begin{array}{l}\text { Model } \\
\text { number }\end{array}$ & Model & $K$ & Likelihood & $\Delta \mathrm{AIC}^{\mathrm{a}}$ & $w_{\mathrm{i}}$ & $\begin{array}{c}P- \\
\text { ANODEV }\end{array}$ \\
\hline 1 & BS $(\operatorname{Exp}+t)$ & 16 & 1.00 & 0.00 & 0.67 & \\
\hline 2 & BS $\left(\operatorname{Exp}^{*} \mathrm{t}\right)$ & 26 & 0.48 & 1.46 & 0.32 & \\
\hline 3 & $\mathrm{BS}(\mathrm{t})$ & 13 & 0.02 & 7.74 & 0.01 & \\
\hline 4 & $\mathrm{BS}\left(\operatorname{Exp}+\mathrm{Pp}_{\mathrm{b}}\right)$ & 7 & 0.00 & 67.42 & 0.00 & 0.05 \\
\hline 5 & BS $\left(\mathrm{Exp}^{*} \mathrm{Pp}_{\mathrm{b}}\right)$ & 8 & 0.00 & 70.90 & 0.00 & 0.18 \\
\hline 6 & $\mathrm{BS}\left(\operatorname{Exp}+\mathrm{SRI}_{\mathrm{w}}\right)$ & 7 & 0.00 & 89.38 & 0.00 & 0.17 \\
\hline 7 & $\mathrm{BS}\left(\mathrm{Exp}+\mathrm{NAO}_{\mathrm{w}}\right)$ & 7 & 0.00 & 90.34 & 0.00 & 0.18 \\
\hline 8 & $\mathrm{BS}\left(\mathrm{Exp}+\mathrm{NDVI}_{\mathrm{w}}\right)$ & 7 & 0.00 & 98.84 & 0.00 & 0.28 \\
\hline 9 & $\mathrm{BS}()$. & 3 & 0.00 & 116.90 & 0.00 & \\
\hline
\end{tabular}

${ }^{\text {a }}$ The lowest AIC value was 2156.0.

experienced at breeding fluctuated in a parallel fashion over time. The difference between inexperienced and experienced birds remained the same in good (i.e., high breeding success or high survival) and in bad (i.e., low breeding success or low survival) years, supporting the idea that birds inexperienced and experienced at breeding respond in the same manner to environmental variability. We hypothesize that storks improved their average performance with increased breeding experience without being able to improve their ability to face climatic fluctuations, at least over the range of climatic variations challenged by the population during our study. If Sahel conditions were not limiting for storks, experience-based differences between individuals may not have persisted, supporting the idea that, under milder conditions, all birds were equally able to successfully survive winters, whatever the relative interannual variation.

Two main hypotheses are generally considered to explain an increase in breeding performance with age or experience: a progressive increase in both foraging skills and in the synchronization of breeding activities through learning (Curio 1983, Greig et al. 1983, Forslund and Pärt 1995) or a progressive decrease in the proportion of lower quality individuals among cohorts through natural selection (Curio 1983, Cam and Monnat 2000, Forslund and Pärt 1995, Barbraud and Weimerskirch 2005). In this White Stork population, the productivity of individuals breeding for the first time was lower because they produced slightly smaller clutches (CB, unpubl. data) and had a higher rate of breeding failure. But the variance in their breeding success was not larger than that of experienced birds, suggesting that all breeding birds may 
reproduce less well during their first breeding events than during the following events. This result is consistent with what would be expected given a learning process. In addition, high winter mortality occurred in birds following their first breeding season, even though inexperienced birds produced fewer fledglings on average compared to experienced breeders. This is probably true for both sexes, as parents appear to provide similar levels of care (Géroudet 1994). This reflects an important cost associated with the first reproduction, as birds not able to successfully face the energy demands of breeding might enter the winter period in poorer condition. But this cost appears to be highly variable from one bird to another, as the variance for survival probability is high. Presumably, among birds breeding for the first time, those subject to the highest cost of reproduction would die. Such differences in mortality may suggest selection on higher reproductive cost, favoring birds able to maximize their survival. As adult survival is a key parameter in such a long-lived species (Sæther and Bakke 2000), this selection process would potentially be driven by the necessity to maintain low mortality to preserve the population growth rate. Interestingly, we observed that higher survival probabilities in experienced storks was associated to increased breeding success, resulting in a progressive decrease in the proportion of lower quality individuals among cohorts (Curio 1983, Forslund and Pärt 1995, Cam and Monnat 2000, Barbraud and Weimerskirch 2005). Consistent with this, our analyses demonstrate that the difference between storks inexperienced and experienced at breeding might be related to a selection process as young adults become experienced just after the first reproductive event. Thus, the first reproductive occasion may be considered a key event for White Storks, where mean breeding performance as well as the survival probability increases over time in the population, facilitated by a combination of learning and selection processes.

\section{ACKNOWLEDGMENTS}

We are particularly grateful to all the field workers involved in the monitoring programs over the past 20 years on the White Stork in Charente-Maritime, France (supported by members of the Groupe Ornithologique Aunis Saintonge). We thank K. Delord for data management, M. Barbraud, J. and L. Biron, and D. and M. Brochard for help in building and settling artificial nests. The Centre de Recherches sur la Biologie des Populations d'Oiseaux supervised the White Stork banding program in France. We are indebted to all the land owners who let us set artificial nests on their proprieties, the Sociétées de Chasse de Saint Jean d'Angle and d'Ars sur Gironde, to Electricité de France, the Parc Naturel Régional du Marais Poitevin, the Association de Défense de l'Environnement de Vendée and the Association Multidisciplinaire des Biologistes de l'Environnement. We thank the Région Poitou-Charentes (grant MN), H. Weimerskirch for helpful comments on the manuscript, M. Authier for his help on mixed model analysis, and J. A. Rodgers Jr., D. S. Dobkin, and an anonymous reviewer, who provided helpful comments and suggestions for improving the manuscript.

\section{LITERATURE CITED}

Archaux, F., G. Balanca, P. Y. Henry, and G. Zapata. 2004. Wintering of White Storks in Mediterranean France. Waterbirds 27:441-445.

BARBRAUD, C., AND J.-C. BARBRAUD. 1997. Le régime alimentaire des poussins de Cigogne Blanche Ciconia ciconia en CharenteMaritime: importance des insectes. Alauda 65:259-262.

Barbraud, C., J.-C. Barbraud, And M. Barbraud. 1999. Population dynamics of the White Stork Ciconia ciconia in western France. Ibis 141:469-479.

Barbraud, C., J.-C. Barbraud, M. Barbraud, and K. Delord. 2002. Changements récents dans le régime alimentaire des poussins de Cigogne Blanche Ciconia ciconia en Charente-Maritime (centre-ouest, France). Alauda 70:437-444.

BARBRAUd, C., AND H. WeIMERSKIRCH. 2005. Environmental conditions and breeding experience affect costs of reproduction in Blue Petrels. Ecology 86:682-692.

Berthold, P., W. Van den Bossche, W. Fiedler, C. Kaatz, M. KaAtZ, Y. Leshem, E. NowaK, AND U. Querner. 2001. Detection of a new important staging and wintering area of the White Stork Ciconia ciconia by satellite tracking. Ibis 143:450-455.

Bunce, A., S. J. WARD, AND F. I. NoRMAN. 2005. Are age-related variations in breeding performance greatest when food availability is limited? Journal of Zoology 266:163-169.

Burnham, K. P., AND D. R. Anderson. 1998. Model selection and inference: a practical information-theoretic approach. Springer-Verlag, New York.

CAM, E., AND J.-Y. MonNat. 2000. Apparent inferiority of first-time breeders in the Kittiwake: the role of heterogeneity among age class. Journal of Animal Ecology 69:380-394.

Chen, M., P. Xie, J. E. Janowiak, And P. A. Arkin. 2002. Global land precipitation: a 50-yr monthly analysis based on gauge observations. Journal of Hydrometeorology 3:249-266.

Choquet, R., A. M. Reboulet, R. Pradel, O. Gimenez, and J. D. LEBreton. 2003. User's manual for U-Care. CEFE/CNRS, Montpellier, France.

Choquet, R., A. M. Reboulet, R. Pradel, O. Gimenez, and J. D. LEBRETON. 2004. M-SURGE: new software specifically designed for multistate capture-recapture models. Animal Biodiversity and Conservation 27:207-215.

Clutton-Brock, T. H., I. R. Stevenson, P. Marrow, A. D. MacColl, A. I. Houston, and J. M. McNamara. 1996. Population fluctuations, reproductive costs and life-history tactics in female Soay Sheep. Journal of Animal Ecology 65:675-689.

Coulson, T., E. A. Catchpole, S. D. Albon, B. J. T. Morgan, J. M. Pemberton, T. H. Clutton-Brock, M. J. Crawley, AND B. T. Grenfell. 2001. Age, sex, density, winter, weather, and population crashes in Soay Sheep. Science 292:1528-1531.

CuRIO, E. 1983. Why do young birds reproduce less well? Ibis 125:400-404.

Erikstad, K. E., P. Fauchald, T. Tverra, and H. Steen. 1998. On the cost of reproduction in long-lived birds: the influence of environmental variability. Ecology 79:1781-1788.

Forslund, P., AND T. PÄRT. 1995. Age and reproduction in birds: hypotheses and tests. Trends in Ecology \& Evolution 10:374-378.

Gaillard, J.-M., D. Delorme, J.-M. Boutin, G. Van Laere, B. BoISAUBERT, AND R. PRADEL. 1993. Roe deer survival patterns: a comparative analysis of contrasting populations. Journal of Animal Ecology 62:778-791.

Gaillard, J.-M., M. Festa-Bianchet, and N. G. Yoccoz. 1998. Population dynamics of large herbivores: variable recruitment with constant adult survival. Trends in Ecology \& Evolution 13:58-63. 
Gaillard, J.-M., M. Festa-Bianchet, N. G. Yoccoz, A. Loison, AND C. ToÏGO. 2000. Temporal variation in fitness components and population dynamics of large herbivores. Annual Review of Ecology and Systematic 31:367-393.

GÉROUDET, P. 1994. Grands échassiers, gallinacés, râles d'Europe. Delachaux et Niestlé, Paris, France.

Global InVEntory Modeling and Mapping Studies. [ONLINE]. 2006. UMD GLCF GIMMS NDVIg global ndvi: NDVI data. <http://iridl.ldeo.columbia.edu/SOURCES/.UMD/. GLCF/.GIMMS/.NDVIg/.global/.ndvi/> (13 October 2007).

Greig, S. A., J. C. Coulson, And P. Monaghan. 1983. Age-related differences in foraging success in the Herring Gull (Larus argentatus). Animal Behaviour 31:1237-1243.

HuRRELL, J. W. 1995. Decadal trends in the North Atlantic Oscillation: regional temperatures and precipitation. Science 269:676-679.

Hurrell, J. W. [ONLINE]. 2006. Winter (Dec-Mar) station based NAO index. <http://www.cgd.ucar.edu/cas/jhurrell/nao.stat. winter.html> (13/10/2007).

IHAKA, R., AND R. GENTLEMAN. 1996. R: a language for data analysis and graphics. Journal of Computational and Graphical Statistics 5:299-314.

JANOWIAK, J. E. 1988. An investigation of interannual rainfall variability in Africa. Journal of Climate 1:240-255.

Kanyamibwa, S., F. Bairlein, AND A. Shierer. 1993. Comparison of survival rates between populations of the White Stork Ciconia ciconia in Central Europe. Ornis Scandinavia. 24:397-302.

Kanyamibwa, S., A. Schierer, R. Pradel, and J. D. Lebreton. 1990. Changes in adult annual survival rates in a western European population of the White Stork Ciconia ciconia. Ibis 132:27-35.

LAAKSONEN, T., E. KorPIMÄKI, AND H. HAKKARAINEN. 2002. Interactive effects of parental age and environmental variation on the breeding performance of Tengmalm's Owls. Journal of Animal Ecology 71:23-31.

Lebreton, J. D., K. P. Burnham, J. Clobert, AND D. R. Anderson. 1992. Modeling survival and testing biological hypotheses using marked animals: a unified approach with case studies. Ecological Monographs 62:67-118.

Mitchell, T. P. [ONLINE]. 2005. Sahel rainfall index (20-10N, 20W10E), 1898-2004. <http://jisao.washington.edu/data/sahel/> (13 October 2007).

NATIONAL OCEANIC AND ATMOSPHERIC ADMINISTRATION. [ONLINE]. 2006. NOAA NCEP CPC PRECL: precipitation rate data. $<$ http://iridl.ldeo.columbia.edu/SOURCES/. NOAA/.NCEP/.CPC/.PRECL/.prcp> (13 October 2007).

Nevoux, M., H. Weimerskirch, and C. Barbraud. 2007. Environmental variation and experience-related differences in the demography of the long-lived Black-browed Albatross. Journal of Animal Ecology 76:159-167.

Newton, I. 1998. Population limitation in birds. Academic Press, London.

Ottersen, G., B. Planque, A. Belgrano, E. Post, P. C. Reid, and N. C. Stenseth. 2001. Ecological effects of the North Atlantic Oscillation. Oceanologia 128:1-14.

PFISTER, C. 2005. Patterns of variance in stage-structured populations: evolutionary predictions and ecological implications. Proceedings of the National Academy of Sciences USA. 95:213218.

Ratcliffe, N., R. W. Furness, and K. C. Hamer. 1998. The interactive effects of age and food supply on the breeding ecology of Great Skuas. Journal of Animal Ecology 67:853862.

Reid, J. M., E. M. Bignal, S. Bignal, D. I. McCracken, And P. Monaghan. 2003. Age-specific reproductive performance in
Red-billed Choughs Pyrrhocorax pyrrhocorax: patterns and processes in a natural population. Journal of Animal Ecology 72:765776.

SÆTHER, B.-E., AND Ø. BAKKE. 2000. Avian life history variation and contribution of demographic traits to the population growth rate. Ecology 81:642-653.

SÆther, B.-E., V. Grøtan, P. Tryjanowski, C. Barbraud, S. Engen, AND M. Fulin. 2006. Climate and spatio-temporal variation in the population dynamics of a long distance migrant, the White Stork. Journal of Animal Ecology 75:80-90.

SCHAUB, M., W. KANIA, AND U. KÖPPEN. 2005. Variation in primary production during winter induces synchrony in survival rates in migratory White Storks Ciconia ciconia. Journal of Animal Ecology 74:656-666.

Skalski, J. R., A. Hoffmann, and S. G. Smith. 1993. Testing the significance of individual- and cohort-level covariates in animal survival studies, p. 9-28. In J. D. Lebreton and P. M. North [EDS.], Marked individuals in the study of bird population. Birkhäuser Verlag, Basel, Switzerland.

Stenseth, N. C., A. Mysterud, G. Ottersen, J. W. Hurrell, K. S. CHAN, AND M. LiMA. 2002. Ecological effects of climate fluctuations. Science 297:1292-1296.

Thompson, P. M., And J. C. Ollason. 2001. Lagged effects of ocean climate change on Fulmar population dynamics. Nature 413:417-420.

Tucker, C. J., J. E. Pinzon, M. E. Brown, D. Slayback, E. W. Pak, R. Mahoney, E. Vermote, and N. El Saleous. 2005. An extended AVHRR 8-km NDVI data set compatible with MODIS and SPOT vegetation NDVI data. International Journal of Remote Sensing 26:4485-4498.

Viallefont, A., F. CoOKe, AND J. D. Lebreton. 1995. Age-specific costs of first-time breeding. Auk 112:67-76.

WEIMERSKIRCH, H. 1990. The influence of age and experience on breeding performance of the Antarctic Fulmar, Fulmarus glacialoides. Journal of Animal Ecology 59:867875.

White, C. G., AND K. P. BuRnhaM. 1999. Program MARK: survival estimation from populations of marked animals. Bird Study 46:S120-S139.

APPENDIX. Number of White Storks (Ciconia ciconia) inexperienced and experienced at breeding in the population at CharenteMaritime, France during the study period.

\begin{tabular}{lccc}
\hline \hline $\begin{array}{l}\text { Breeding } \\
\text { season }\end{array}$ & $\begin{array}{c}\text { Inexperienced } \\
\text { birds }\end{array}$ & $\begin{array}{c}\text { Experienced } \\
\text { birds }\end{array}$ & Total \\
\hline 1992 & 6 & 5 & 11 \\
1993 & 19 & 10 & 29 \\
1994 & 24 & 8 & 32 \\
1995 & 15 & 27 & 42 \\
1996 & 20 & 29 & 49 \\
1997 & 20 & 46 & 66 \\
1998 & 27 & 50 & 77 \\
1999 & 19 & 55 & 74 \\
2000 & 31 & 63 & 94 \\
2001 & 24 & 70 & 94 \\
2002 & 26 & 71 & 97 \\
2003 & 6 & 53 & 59 \\
Total & 237 & 487 & 724 \\
\hline
\end{tabular}

